\title{
Correction to: Summertime precipitation in Hokkaido and Kyushu, Japan in response to global warming
}

\author{
Daichi Takabatake $^{1}$ (D) Masaru Inatsu ${ }^{2}$
}

(c) The Author(s) 2022

\section{Correction to: Climate Dynamics https://doi.org/10.1007/s00382-021-05983-7}

The article "Summertime precipitation in Hokkaido and Kyushu, Japan in response to global warming", written by Daichi Takabatake, Masaru Inatsu was originally published electronically on the publisher's internet portal on 31 October 2021 without open access. With the author(s)' decision to opt for Open Choice the copyright of the article changed on 25 February 2022 to (c) The Author(s) 2021 and the article is forthwith distributed under a Creative Commons Attribution 4.0 International License, which permits use, sharing, adaptation, distribution and reproduction in any medium or format, as long as you give appropriate credit to the original author(s) and the source, provide a link to the Creative Commons licence, and indicate if changes were made. The images or other third party material in this article are included in the article's Creative Commons licence, unless indicated otherwise in a credit line to the material. If material is not included in the article's Creative Commons licence and your intended use is not permitted by statutory regulation or exceeds the permitted use, you will need to obtain permission directly from the copyright holder. To view a copy of this licence, visit http://creativecommons. org/licenses/by/4.0. Open access funding enabled and organized by Projekt DEAL.

The original article was corrected.

Open Access This article is licensed under a Creative Commons Attribution 4.0 International License, which permits use, sharing, adaptation, distribution and reproduction in any medium or format, as long as you give appropriate credit to the original author(s) and the source, provide a link to the Creative Commons licence, and indicate if changes were made. The images or other third party material in this article are included in the article's Creative Commons licence, unless indicated otherwise in a credit line to the material. If material is not included in the article's Creative Commons licence and your intended use is not permitted by statutory regulation or exceeds the permitted use, you will need to obtain permission directly from the copyright holder. To view a copy of this licence, visit http://creativecommons.org/licenses/by/4.0/.

Publisher's Note Springer Nature remains neutral with regard to jurisdictional claims in published maps and institutional affiliations.

The original article can be found online at https://doi.org/10.1007/ s00382-021-05983-7.

Daichi Takabatake

tkbd1070@gmail.com

1 Obihiro Weather Station, Japan Meteorological Agency, E4 S9, Obihiro, Hokkaido, Japan

2 Faculty of Science and Center for Natural Hazards Research, Hokkaido University, Sapporo, Japan 